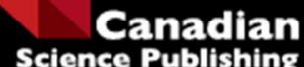

Canadian Journal of Earth Sciences Revue canadienne des sciences de la Terre

\title{
Is the Lomagundi Event present on the Rae craton? A case study from the Murmac Bay Group
}

\begin{tabular}{|r|l|}
\hline Journal: & Canadian Journal of Earth Sciences \\
\hline Manuscript ID & cjes-2015-0186.R1 \\
\hline Manuscript Type: & Article \\
\hline Date Submitted by the Author: & $28-$ Feb-2016 \\
\hline Complete List of Authors: & $\begin{array}{l}\text { McDonald, Brayden; University of Saskatchewan, Geological Sciences } \\
\text { Partin, Camille; University of Saskatchewan, Geological Sciences }\end{array}$ \\
\hline Keyword: & $\begin{array}{l}\text { carbon isotopes, Paleoproterozoic, Canadian Shield, carbonates, Lomagundi } \\
\text { Event }\end{array}$ \\
\hline &
\end{tabular}

\section{SCHOLARONE" \\ Manuscripts}




\title{
Is the Lomagundi Event present on the Rae craton? A case study from the Murmac Bay Group
}

\author{
Brayden McDonald ${ }^{1}$ and Camille A. Partin ${ }^{1 *}$ \\ ${ }^{1}$ University of Saskatchewan, Department of Geological Sciences, 114 Science Place, \\ Saskatoon, SK S7N 5E2, Canada ; brayden.mcdonald@usask.ca, \\ camille.partin@usask.ca \\ *corresponding author \\ E-mail: camille.partin@usask.ca; phone: 1-306-966-5719
}

https://mc06.manuscriptcentral.com/cjes-pubs 
1 Is the Lomagundi Event present on the Rae craton? A case study from the Murmac

4 Abstract: Shortly after the initial rise of atmospheric oxygen in the Paleoproterozoic Era, 5 a major perturbation occurred in the global carbon cycle, which is manifested as a long-

6 lived positive carbon isotope excursion recorded in $\sim 2.22$ to $2.06 \mathrm{Ga}$ carbonate rocks, 7 known as the Lomagundi Event. Beyond its significance for evolving seawater 8 composition, this geochemical event can be used as an indirect age marker in

9 Paleoproterozoic sedimentary successions. Documenting further occurrences of this event

10 in other Paleoproterozoic carbonate rocks confirms that the event was global and reflects

11 ambient seawater composition. This event, however, has only been documented in two

12 successions in Canada, despite the ubiquity of Paleoproterozoic-aged rocks on the

13 Canadian Shield. Our study focuses on metacarbonate rocks from the Paleoproterozoic-

14 aged Murmac Bay Group on the southwestern margin of the Rae craton in northern

15 Saskatchewan. Measured $\delta^{13} \mathrm{C}$ values (up to $7.8 \%$ ) fall within the range of the

16 Lomagundi Event, but most values are relatively low, suggesting $\mathrm{CO}_{2}$ loss

17 (decarbonation) altered the $\delta^{13} \mathrm{C}$ values. Stable carbon isotope data coupled with major

18 element geochemical data allowed us to account for the degree to which the values have

19 changed due to metamorphic $\mathrm{CO}_{2}$ loss. We also compare $\delta^{13} \mathrm{C}$ values from micro-drilled

20 (dolomite and calcite phases) to whole-rock $\delta^{13} \mathrm{C}$ values from the same samples to 21 characterize the $\delta^{13} \mathrm{C}$ composition of pre-metamorphic carbonate minerals. Both

22 measured and corrected $\delta^{13} \mathrm{C}$ values place the Murmac Bay Group metacarbonates within 
23 the range of values that characterize the Lomagundi Event and indicate, for the first time,

24 the presence of the Lomagundi Event on the Rae craton.

26 Key words: Paleoproterozoic, carbonates, Lomagundi Event, carbon isotopes, Canadian

27 Shield 


\section{Introduction}

29 Several Paleoproterozoic-aged marine carbonate successions deposited between

$30 \sim 2.22$ and $2.06 \mathrm{Ga}$ record anomalously high $\delta^{13} \mathrm{C}$ values ranging from $4 \%$ to $16 \%$ (e.g.,

31 Schidlowski et al. 1975; Karhu and Holland 1996; Melezhik et al. 1999; Planavsky et al.

32 2012; Martin et al. 2013). This event is known as the Lomagundi positive carbon isotope

33 excursion, or Lomagundi Event, after its discovery in the Lomagundi Group of

34 Zimbabwe (Melezhik et al. 2005). These highly positive $\delta^{13} \mathrm{C}$ values found within

35 Paleoproterozoic carbonate rocks have been attributed to an organic carbon burial event

36 that resulted in a large influx of atmospheric oxygen (Karhu and Holland 1996) that post-

37 dates the onset of the Great Oxidation Event (Lyons et al. 2014). The Lomagundi Event

38 has been documented in more than 22 locations worldwide, contributing to the idea that

39 the Lomagundi Event records a significant perturbation to the global carbon cycle (Karhu

40 and Holland 1996; Maheshwari et al. 2010a; Martin et al. 2013). However, some

41 metasedimentary successions of this age experienced higher grades of metamorphism,

42 especially in widespread 1.9 to $1.7 \mathrm{Ga}$ orogens, which likely depleted carbonate $\delta^{13} \mathrm{C}$

43 values. Therefore, identifying the Lomagundi Event in these successions presents a

44 challenge, but higher metamorphic grade rocks have the potential to show that the

45 geographical extent of the Lomagundi Event is larger than currently known. Previous

46 studies have shown that near-to primary $\delta^{13} \mathrm{C}$ values can be retained in amphibolite and

47 even granulite facies metacarbonate rocks (e.g., Bol et al. 1995). Finding evidence of a

48 positive carbon isotope excursion in higher-grade rocks is promising since metamorphism

49 tends to drive $\delta^{13} \mathrm{C}$ values lighter, therefore measurement of carbon isotope values in

50 metamorphosed carbonates has the potential to identify high $\delta^{13} \mathrm{C}$ values indicative of the 
51 Lomagundi Event. To our knowledge, the Lomagundi Event has only been documented

52 in two amphibolite-grade carbonate successions previously (Melezhik et al. 2003; Master

53 et al. 2013). This validates the possibility that the Lomagundi Event can be preserved in

54 higher metamorphic grade rocks. Thus, if the Lomagundi Event is truly global in extent

55 and recording seawater composition, all marine carbonate successions deposited in this

56 time interval should show a record of the event.

57 The Lomagundi Event has not yet been described from a Paleoproterozoic 58 succession on the Rae craton. The Murmac Bay Group (MBG) is a Paleoproterozoic-aged

59 metasedimentary succession located on the southwestern margin of the Rae craton in

60 northern Saskatchewan, Canada. Current age constraints suggest that the entire MBG was

61 deposited sometime after $2.33 \mathrm{Ga}$ and before $1.94 \mathrm{Ga}$, the latter of which records the

62 onset of metamorphism to the amphibolite facies (Ashton et al. 2013; Bethune et al.

63 2013). Importantly, the available age constraints overlap the time interval of the

64 Lomagundi Event. The lower MBG succession includes metacarbonate rocks, which

65 provide an opportunity to test for the presence or absence of the Lomagundi Event.

66 Finding highly positive $\delta^{13} \mathrm{C}$ values indicative of the Lomagundi Event would support the

67 interpretation that the MBG was deposited in a marine environment (Ashton et al. 2013),

68 as well as provide new age constraints on carbonate deposition.

69 We present new stable isotopic data $\left(\delta^{13} \mathrm{C}\right.$ and $\delta^{18} \mathrm{O}$ values $)$ in addition to major

70 element geochemistry to test for the presence or absence of the Lomagundi Event in

71 MBG metacarbonate rocks. We also address the impact of $\mathrm{CO}_{2}$ loss (decarbonation) from

72 metamorphic mineral transformations within the MBG metacarbonate rocks on their

73 isotopic compositions. 


\section{Geological Setting}

76 The Paleoproterozoic-aged MBG was deposited near the margin of the

77 southwestern Rae craton on the Beaverlodge Domain, and is presently exposed on the

78 northern edge of Lake Athabasca in northwest Saskatchewan, Canada (Figure 1). Much

79 of the northern Canadian Shield is underlain by the Rae craton, which is bounded to the

80 southeast by the Hearne craton and separated by the Snowbird tectonic zone (Figure 1).

81 These two Archean cratons comprise the larger western Churchill province in northern

82 Canada. The northwestern margin of the Rae craton is bounded by the Proterozoic-aged

83 Taltson magmatic zone (Hoffman, 1988; Ashton et al. 2013) that separates the Rae craton

84 from the Archean Slave craton. The southwestern Rae craton is composed largely of 3.0

85 to $2.6 \mathrm{Ga}$ basement rocks, with a number of granitic intrusive suites at $2.5-2.46 \mathrm{Ga}, 2.33$

$86-2.29 \mathrm{Ga}$, and $1.93-1.91 \mathrm{Ga}$ (Ashton et al. 2013).

87 The MBG is a multiply-deformed metasedimentary succession with at least two 88 recognized events of deformation, the Talston (1.94 - 1.93 Ga) and the Snowbird orogens

89 (1.91 - $1.90 \mathrm{Ga})$ (Hartlaub et al. 2004; Ashton et al. 2013; Bethune et al. 2013). The

90 Beaverlodge Domain was intruded by granitic rocks that were associated with the Taltson

91 Orogeny, during which the MBG was metamorphosed to amphibolite to granulite facies

92 between 1.94 to 1.91 Ga (Figure 1; Ashton et al. 2013; Bethune et al. 2013). The MBG

93 lies unconformably on top of Archean basement rocks, some of which have been dated,

94 including the 3.0 Ga Elliot Bay and Cornwall Bay granites (Hartlaub et al. 2004;

95 Bethune et al. 2013). The dominant lithologies of the MBG are quartzite, basalt,

96 psammite, and pelite, with thin units of banded iron formation and carbonate (Hartlaub et 
97 al. 2004; Ashton et al. 2013) (Figure 2). The lower MBG is composed of a locally

98 occurring polymictic conglomerate that lies unconformably on top of Archean basement

99 rocks. The conglomerate is interbedded within quartzite, which varies locally in thickness

100 (5 to 500m) (Hartlaub et al. 2004). Small scale planar cross bedding and larger scale

101 (meter-scale) trough cross bedding features have been preserved within the quartzite

102 (Hartlaub et al. 2004). Evidence of these locally preserved features suggests that the

103 quartzites might have been deposited in a high-energy fluvial or shoreline environment

104 (Hartlaub et al. 2004). The dolostone that forms the basis of this study occurs within the

105 quartzite unit and varies from two to tens of meters in tectonostratigraphic thickness

106 (Hartlaub et al. 2004) occurring sometimes as isolated pockets within the quartzite

107 (Ashton et al. 2000). The quartzite-dolomite package is overlain by a banded iron

108 formation that consists of cm-thick alternating quartz and magnetite-hematite rich layers,

109 followed by a medium- to fine-grained amphibolite (Hartlaub et al. 2004). The upper

110 MBG consists of a thick package of aluminous psammopelite and pelite that is

111 stratigraphically above and locally interlayered with both the quartzite and the

112 amphibolite (Hartlaub et al. 2004).

\section{Methods}

115 Petrographic, geochemical, and isotopic analysis was performed on

116 metacarbonate rocks of the MBG to test for the presence of the Lomagundi Event.

117 Samples 6-2, 6-2A, and the sample series 9-1 to 9-9 were collected in the field, near

118 Beaverlodge Lake and Goldfields (Figure 1), respectively, within a known stratigraphic

119 context, whereas samples 4700- 0050, -6100, 4709-6001, and 4701-3075A are from the 
120 Saskatchewan Geological Survey archives. Samples were cut into slabs and polished

121 prior to micro-drilling; micro-drilling targeted the calcite and dolomite phases present. A

122 subset of carbonate samples was crushed for whole-rock isotopic and geochemical

123 analysis. Standard carbonate staining techniques were used to determine carbonate

124 mineralogy, which utilized a mixture of Alizarin red-S and potassium ferricyanide

125 (Dickson 1965; Hitzman 1999). Petrographic analysis was done on both stained and

126 unstained thin sections. Isotopic ratios of $\delta^{13} \mathrm{C}$ and $\delta^{18} \mathrm{O}$ from both micro-drilled and

127 whole-rock samples were measured at the University of Saskatchewan Isotope

128 Laboratory at the University of Saskatchewan. Samples were initially roasted in a

129 vacuum oven at $200^{\circ} \mathrm{C}$ for 1 hour to remove water and volatile organic contaminants that

130 can alter isotopic values. Samples were analyzed using a Finnigan Kiel-IV carbonate

131 preparation device directly coupled to the dual inlet of a Finnigan MAT 253 isotope ratio

132 mass spectrometer at the Saskatchewan Isotope Laboratory. Carbonate samples (20-50

133 micrograms) were reacted at $70^{\circ} \mathrm{C}$ with 3 drops of anhydrous phosphoric acid for 420

134 seconds. The $\mathrm{CO}_{2}$ evolved was cryogenically purified before analysis. Isotope ratios are

135 corrected for acid fractionation and ${ }^{17} \mathrm{O}$ contribution using the Craig correction, and

136 reported in per mil (\%) notation relative to the Vienna-Pee Dee Belemnite (V-PDB)

137 scale. Data is directly calibrated against the international standard NBS-19 that has $\delta^{13} \mathrm{C}$

$138=1.95 \%$ (V-PDB) and $\delta^{18} \mathrm{O}=-2.2 \%$ (V-PDB) values. Precision and accuracy are

139 monitored through routine analysis of NBS-19 and in-house check standards calibrated

140 against NBS-19. Analytical error and reproducibility of $\delta^{13} \mathrm{C}$ and $\delta^{18} \mathrm{O}$ are $0.05 \%$ and

$1410.11 \%$, respectively $(\mathrm{n}=25)$. Dolomite $\delta^{18} \mathrm{O}$ values are calculated using the following 
142 fractionation factors at $70^{\circ} \mathrm{C}$ : calcite $=1.008698($ Swart et al. 1991) dolomite $=1.009926$

143 (Rosenbaum and Sheppard 1986).

144 Whole-rock major element geochemical analysis was conducted at Activation 145 Labs in Ontario (their 4C - XRF Fusion package), specifically for $\mathrm{MgO}, \mathrm{CO}_{2}, \mathrm{CaO}$, $146 \mathrm{MnO}_{2} \mathrm{SiO}_{2}$, and $\mathrm{Fe}_{2} \mathrm{O}_{3}$, according to the heavy absorber fusion technique of Norrish and 147 Hutton (1969). Loss on ignition (LOI) of $\mathrm{H}_{2} \mathrm{O}^{+}, \mathrm{CO}_{2}, \mathrm{~S}$, and other volatiles, is determined 148 from the weight loss once the sample has been roasted at $1050^{\circ} \mathrm{C}$ for 2 hours. The fusion 149 disk is created from the mixing of $0.5 \mathrm{~g}$ equivalent of the roasted sample with a $6.5 \mathrm{~g}$ 150 combination of lithium metaborate and lithium tetraborate with a releasing agent of 151 lithium bromide. Samples were analyzed on a Panalytical Axios Advanced wavelength 152 dispersive XRF. The detection limit is about $0.01 \mathrm{wt} \%$ for most elements.

153 The $\mathrm{CO}_{2}$ analysis was conducted at Activation labs (their $4 \mathrm{~F}-\mathrm{CO}_{2}$ infrared (IR)

154 package $)$. Samples (0.2 g) were thermally decomposed in a pure nitrogen environment at $1551000^{\circ} \mathrm{C}$, using an ELTRA CW-800, directly releasing $\mathrm{CO}_{2} \cdot \mathrm{H}_{2} \mathrm{O}$ is removed from the 156 system before the detection of $\mathrm{CO}_{2}$. IR energy is then absorbed by the $\mathrm{CO}_{2}$ at a precise 157 wavelength. IR calibration is achieved using pure calcium carbonate standard (USZ 25158 2006). This method has a detection limit of $0.01 \%$.

160 Results

161 The $\delta^{13} \mathrm{C}$ values for the micro-drilled samples show a wide range (9\%o), with a 162 minimum value of $-1.2 \%$, a maximum value of $+7.8 \%$, and an average value of $+1.1 \%$. 163 Associated $\delta^{18} \mathrm{O}$ values show a range of $7 \%$, with a maximum value of $+18.0 \%$ and a 164 minimum value of $-10.9 \%$ with an average value of $-15.5 \%$. By contrast, the whole-rock 
$165 \delta^{13} \mathrm{C}$ show lower values overall: $-4.1 \%$ (minimum), 5.3\%o (maximum), and $0.1 \%$ 166 (average), but a similar range of values (9.4\%o). The associated $\delta^{18} \mathrm{O}$ values show a range 167 of $4.4 \%$ and a minimum of $-18.4 \%$ and maximum of $-14.0 \%$, with an average value of -

168 16.3\% (Table 1). Petrographic analysis shows that the major mineral composition of the 169 samples varies between ferroan and non-ferroan dolomite \pm tremolite (Table 2; Figure 3).

170 However, calcite and quartz are present in some samples, as is magnetite (trace). Where 171 present, the quartz typically shows a xenotopic mosaic texture or is present as an 172 overgrowth on the dolomite. Results from whole-rock geochemical analysis show $173 \mathrm{MgO} / \mathrm{CaO}$ ratios that are similar or slightly below that of stoichiometric dolomite $(0.71$;

174 Table 3). Whole-rock geochemical data was coupled with whole-rock $\delta^{13} \mathrm{C}$ values to 175 assess the impact of $\mathrm{CO}_{2}$ loss (decarbonation) that occurred through metamorphism. We 176 use Rayleigh fractionation calculations to estimate the post-burial alteration of whole177 rock $\delta^{13} \mathrm{C}$ values that occurred through decarbonation (Table 3).

\section{Discussion}

180 Petrographic analysis and mineral paragenesis

181 Though the MBG carbonates now contain dolomite, calcite, and tremolite as the 182 dominant mineralogical assemblage, the pre-metamorphic mineralogy was likely 183 dominated by dolomite (Figure 3A). The presence of tremolite requires that dolomite was 184 a large component of the pre-metamorphic carbonate mineralogy, in order to account for 185 the $\mathrm{Mg}$ requirement of the tremolite present within the samples. The following equation 186 is the most likely reaction for the formation of tremolite (Winkler 1979; Melezhik et al. 187 2003): 5 dolomite +8 quartz $+1 \mathrm{H}_{2} \mathrm{O} \rightarrow 1$ tremolite +3 calcite $+7 \mathrm{CO}_{2}$ 
The presence of twinned calcite crystals indicates the metamorphic

189 recrystallization of calcite (Figure 3B). Though calcite is likely present in both pre-

190 metamorphic and metamorphic phases, this could not be distinguished petrographically.

191 Tremolite overgrowth of the calcite is observed in thin section (Figure 3B), as well as

192 pitting that can indicate the presence of alkaline rich fluids interacting with the

193 preexisting calcite. Melezhik et al. (2003) and Črne et al. (2014) demonstrated the

194 importance of targeting pre-metamorphic carbonate minerals (typically dolomite) via

195 micro-drilling, which reflects the best approximation of primary $\delta^{13} \mathrm{C}$ values. In epidote-

196 amphibolite facies dolostones, post-metamorphic calcite was shown to record lighter $\delta^{13} \mathrm{C}$

197 values as compared to pre-metamorphic calcite (Melezhik et al. 2003). Given this

198 framework, we targeted both dolomite and calcite phases via micro-drilling as part of our

199 isotopic analysis to test for primary and secondary isotopic signals. Accordingly, our

200 micro-drilled dolomite samples record the highest $\delta^{13} \mathrm{C}$ values, while micro-drilled calcite

201 yielded lower values (Table 1). In one case, the $\delta^{13} \mathrm{C}$ value of micro-drilled calcite is

202 identical to the whole-rock isotopic value of $1.1 \%$ (Table 1, Figure 4A), which is

203 consistent with the presence of metamorphic calcite in the sample.

205 Assessment of isotopic values

206 Previously documented Lomagundi Event $\delta^{13} \mathrm{C}$ values range from $+4.6 \%$ to 207 +16.6\%o (e.g., Baker and Fallick 1989a; Baker and Fallick 1989b; Karhu 1993; Karhu 208 and Holland 1996; Melezhik et al. 1997; Bekker et al. 2003; Bekker et al. 2006; Tang et 209 al. 2011). By contrast, some of the $\delta^{13} \mathrm{C}$ values from the MBG (Table 3 ) fall within this 210 range, but show lower than average values overall. The micro-drilled and whole-rock 
211 average $\delta^{13} \mathrm{C}$ values are $+1.1 \%$ and $+0.1 \%$ respectively, which are lower than the global

212 Lomagundi Event average value (+4.7\%) (Maheshwari et al. 2010). However, due to the

213 higher metamorphic grade of our samples, the lower values can be attributed to

214 decarbonation processes, including the transformation of pre-metamorphic carbonate

215 minerals to tremolite. Regardless of metamorphic grade, our two highest measured values

216 (5.3\%o whole-rock and 7.8\%o micro-drilled) do fall within the established range of

217 Lomagundi Event values. In the following, we consider the extent to which the MBG

218 metacarbonates experienced $\mathrm{CO}_{2}$ loss and conclude that the measured $\delta^{13} \mathrm{C}$ values likely

219 underestimate the primary values by a minimum of 4\%. Therefore the majority of our

220 corrected values are consistent with other worldwide Lomagundi Event values.

221 In order to estimate the extent to which $\delta^{13} \mathrm{C}$ values decreased from their initial

222 values, we looked at two possible models - Rayleigh and batch distillation. By assuming

223 the rock devolatized within a closed system, the $\delta^{13} \mathrm{C}$ will vary directly with the degree of

224 devolatilization in accordance with mass balance. However, the more likely case is a

225 continuous decarbonation reaction, where there is an ongoing exchange and removal of

226 small amounts of fluid (Valley 1986), therefore we use the following equation, the

227 Rayleigh fractionation model: $\delta^{f}=\delta^{i}+10^{3}\left(F^{\alpha-1}-1\right)$, where $F$ is the mole fraction of

228 carbon that remains in the rock after volatilization, $\alpha$ is the isotopic fractionation factor,

229 and lastly, $\delta^{i}$ and $\delta^{f}$ are the initial and final isotopic values of the rock in standard per mil

230 notation. Rayleigh fractionation approximates the effects of decarbonation within an

231 impure (quartz-bearing) dolomitic rock better than the alternative batch model. This is

232 supported by our samples, $70 \%$ of which have an $F$ value greater than 0.6 . The shift in

233 the isotopic values of our samples are best described by the Rayleigh model, since F 
234 values are above a threshold value $(>0.6)$ are considered align best with Rayleigh 235 fractionation (Valley 1986).

236 The remaining $\mathrm{CO}_{2}$ within the samples $(F)$ can be determined from the measured

237 amounts of $\mathrm{CO}_{2}, \mathrm{CaO}$, and $\mathrm{MgO}$ of each sample by assuming that the samples were

238 either dolomite or calcite, depending on their $\mathrm{CaO} / \mathrm{MgO}$ ratio (Table 3). Dolomite

239 samples were identified based on the $\mathrm{MgO} / \mathrm{CaO}$ ratio of stoichiometric dolomite $(0.72)$

240 and all other samples were assumed to be calcite. By assuming that our highest $\delta^{13} \mathrm{C}$

241 value $(+7.8 \%$ o $)$ represents the closest-to-primary $\delta^{13} \mathrm{C}$ value $\left(\delta^{i}\right)$, we calculate the

242 fractionation factor, $\alpha$, and $\Delta^{13} \mathrm{C}_{\text {(CO2- carb) }}$ and estimate the degree to which our $\delta^{13} \mathrm{C}$

243 values have been reset. Our results show that a group of the whole-rock samples have

$244 \delta^{13} \mathrm{C}$ values that were shifted to lighter values by $\sim 4 \%$, while other samples gave

245 unreasonable values (Table 3). In conjunction with these calculations the extent to which

246 our samples experienced decarbonation correlates with the Si content of the sample, that

247 is, samples with greater $\mathrm{Si}$ contents show a higher degree of decarbonation (lower F

248 values) (Figure 4B) due to $\mathrm{Si}$ as the limiting reagent in the reaction of dolomite to

249 tremolite (Valley 1986).

250 The formation of tremolite, present in most of our samples, provides a mechanism

251 for this $\mathrm{CO}_{2}$ loss and the subsequent alteration of initial $\delta^{13} \mathrm{C}$ values. However, there is a

252 large and unrealistic range of values for $\alpha(0.579-1.484)$ and $\Delta^{13} \mathrm{C}$ (CO2- carb) values if

253 only dolomite is considered as the dominant pre-metamorphic mineralogy. For samples

254 that are found within similar metamorphic facies it is unlikely to have the $\Delta^{13} \mathrm{C}$ (CO2- carb)

255 values differ so greatly without an additional source of carbon (cf. Melezhik et al. 2003).

256 The other possible reason for such a varied $\Delta^{13} \mathrm{C}_{(\mathrm{CO} 2 \text { - carb })}$ is that the Rayleigh calculation 
257 in this case is based solely on the assumption that the targeted phases were either 258 dolomite or calcite, as opposed to being a mix of the two.

259 Although the cause of the long-lived positive carbon isotope excursion of the

260 Lomagundi Event is not well-constrained, it is thought to be the result of a large organic

261 carbon burial event (cf. Karhu and Holland 1996; Hayes and Waldbauer 2006). One

262 alternative explanation to produce ${ }^{13} \mathrm{C}$-enriched values in carbonate is the formation of

263 late diagenetic dolomite in the presence of methanogenesis (Yudovich et al. 1991; Dix et

264 al. 1995). Assessing the possibility of diagenetic, specifically methanogenic, dolomite in

265 our samples is not straightforward due to the large degree of metamorphic

266 recrystallization. Though we cannot completely exclude the possibility of methanogenic

267 dolomite formation, we consider this possibility to be less likely given the age constraints

268 of our samples (falling within the Lomagundi Event interval) and recent datasets that

269 provide insight into the predicted consequences of an anomalous organic carbon burial

270 event, as discussed below.

271 The carbon isotopic record of Lomagundi-aged carbonates was originally

272 interpreted to represent a massive organic carbon burial event that led to a marked

273 increase in atmospheric oxygen content (e.g., Karhu and Holland 1996). Since then,

274 multiple independent lines of evidence have confirmed that the Lomagundi Event interval

275 does indeed reflect high oxygen conditions (Bekker and Holland 2012), including

276 elevated concentrations of redox-sensitive trace elements (e.g., Scott et al. 2008; Sahoo et

277 al. 2012; Partin et al. 2013) and sulfate in the oceans (Planavsky et al. 2012; Scott et al.

278 2014), as well as the presence of sulfate evaporite deposits (Schröder et al. 2008). Further

279 evidence from organic carbon isotopes records a massive oxidation of organic matter 
280 after the Lomagundi Event (Kump et al. 2011), consistent with the idea of organic carbon

281 burial driving the positive carbon isotope excursion. Although local processes, including

282 diagenesis, likely have a bearing on the carbon isotopic value of Paleoproterozoic

283 carbonates, the overwhelming majority of evidence points to an organic carbon burial

284 event that led to markedly higher atmospheric oxygen levels. Since the burial of organic

285 carbon is the most important regulator of atmospheric oxygen levels (e.g., Canfield 2005;

286 Holland 2006) and organic carbon burial can explain highly positive carbon isotope

287 values, we consider this to be the most parsimonious explanation for the carbon isotope

288 values recorded during the Lomagundi Event.

290 Implications of documenting a new Lomagundi Event occurrence

291 The results of our study indicate that the $\mathrm{MBG}$ records high $\delta^{13} \mathrm{C}$ values (up to

$292+7.8 \%$ ) that fall within the documented range of $\delta^{13} \mathrm{C}$ values for the Lomagundi Event.

293 The present age constraints for MBG metacarbonates support this, since deposition

294 occurred sometime after 2.33 Ga (Ashton et al. 2013), suggesting the Lomagundi Event

295 might be recorded. The range in values from both micro-drilled and whole-rock analyzed

296 samples of MBG metacarbonates indicates that they are within the range of values

297 observed in the Lomagundi Event worldwide (Table 4). Therefore, this conclusion

298 provides a new (indirect) depositional age constraint for the MBG metacarbonates to be

299 sometime between $\sim 2.22$ and $2.06 \mathrm{Ga}$. Considering the relatively thin nature of the MBG

300 metacarbonates (Figure 2), it is unlikely that our samples capture the entire Lomagundi

301 Event interval. Instead, the lower MBG was deposited sometime during this interval and

302 captured seawater values. 


\section{Conclusions}

305 Based on carbon and oxygen isotope trends and whole-rock geochemical results

306 of MBG metacarbonate rocks, we infer that $\delta^{13} \mathrm{C}$ values in the micro-drilled samples of

307 dolomite record closest to primary carbon isotopic values. The lightest $\delta^{13} \mathrm{C}$ values can be

308 explained by decarbonation reactions and Rayleigh fractionation. The extent of

309 decarbonation, as indicated by $\mathrm{F}$ values, scales with the $\mathrm{Si}$ content of impure

310 metacarbonate samples. Therefore, the impure metacarbonate rocks lost more $\mathrm{CO}_{2}$,

311 shifting their $\delta^{13} \mathrm{C}$ values to lower values. The high $\delta^{13} \mathrm{C}$ values $(\leq+7.8 \%)$ found in the

312 MBG suggest that the Lomagundi Event is recorded in the Murmac Bay metacarbonates,

313 therefore constraining the timing of deposition to be between $\sim 2.22$ and 2.06 Ga.

314 Although the Lomagundi Event has been described from other cratons within Laurentia

315 (e.g., Superior and Wyoming cratons), our study presents the first evidence that the

316 Lomagundi Event was recorded in a succession deposited on the Rae craton and is the

317 first described from western Canada.

\section{Acknowledgments}

320 Field and analytical work was funded by a Geo-mapping for Energy and Minerals

321 (GEM-2) grant (to C.A.P.). B.M. would like to acknowledge D. Besic (Saskatchewan

322 Isotope Laboratory) for help with isotopic analysis, C. Shiels for help with drafting

323 figures, C.K. West for comments on an earlier version of the manuscript, and R. Rule for

324 his help with petrography. The Saskatchewan Geological Survey (K. Ashton) is thanked

325 for providing additional samples for this study. 


\section{References}

Ashton, K.E., Kraus, J., Hartlaub, R.P., and Morelli, R., 2000, Uranium City revisited: a new look at the rocks of the Beaverlodge Mining Camp: Summary of investigations, v. 2, p. 99-4.2.

Ashton, K., Card, C.D., Davis, W., and Heaman, L.M., 2007, New U-Pb zircon age dates from the Tazin Lake map area (NTS 74 N), in Summary of Investigations, 2007, Saskatchewan Geological Survey, Saskatchewan Ministry of Energy and Resources, p. Paper A-11, 8 p.

Ashton, K.E. and Hartlaub, R.P. 2008, Geological compilation of the Uranium City area; Sask. Ministry of Energy and Resources, Open File 2008-5, set of four 1:50,000 scale maps.

Ashton, K.E., Hartlaub, R.P., Bethune, K.M., Heaman, L.M., Rayner, N., and Niebergall, G.R., 2013, New depositional age constraints for the Murmac Bay group of the southern Rae craton, Canada: Paleoproterozoic tectonic assembly of the western Canadian shield: new findings and implications for the reconstruction of Laurentia/Nuna, v. 232, no. 0, p. 70-88, doi: 10.1016/j.precamres.2012.05.008.

Baker, A., and Fallick, A., 1989a, Evidence from Lewisian limestones for isotopically heavy carbon in two-thousand-million-year-old sea water:.

Baker, A., and Fallick, A., 1989b, Heavy carbon in two-billion-year-old marbles from Lofoten-Vesterälen, Norway: Implications for the Precambrian carbon cycle: Geochimica et Cosmochimica Acta, v. 53, no. 5, p. 1111-1115.

Bekker, A., and Holland, H.D., 2012, Oxygen overshoot and recovery during the early Paleoproterozoic: Earth and Planetary Science Letters, v. 317-318, p. 295-304, doi: 10.1016/j.eps1.2011.12.012.

Bekker, A., Karhu, J., Eriksson, K., and Kaufman, A., 2003, Chemostratigraphy of Paleoproterozoic carbonate successions of the Wyoming Craton: tectonic forcing of biogeochemical change? Precambrian Research, v. 120, no. 3, p. 279-325.

Bekker, A., Karhu, J., and Kaufman, A., 2006, Carbon isotope record for the onset of the Lomagundi carbon isotope excursion in the Great Lakes area, North America: Precambrian Research, v. 148, no. 1, p. 145-180.

Bethune, K.M., Berman, R.G., Rayner, N., and Ashton, K.E., 2013, Structural, petrological and U-Pb SHRIMP geochronological study of the western Beaverlodge domain: Implications for crustal architecture, multi-stage orogenesis 
and the extent of the Taltson orogen in the SW Rae craton, Canadian Shield: Paleoproterozoic tectonic assembly of the western Canadian shield: new findings and implications for the reconstruction of Laurentia/Nuna, v. 232, no. 0, p. 89118, doi: 10.1016/j.precamres.2013.01.001.

Canfield, D.E., 2005, The early history of atmospheric oxygen: homage to Robert A. Garrels: Annual Review of Earth and Planetary Sciences, v. 33, p. 1-36.

Črne, A.E., Melezhik, V.A., Lepland, A., Fallick, A.E., Prave, A.R., and Brasier, A.T., 2014, Petrography and geochemistry of carbonate rocks of the Paleoproterozoic Zaonega Formation, Russia: Documentation of 13C-depleted non-primary calcite: Precambrian Research, v. 240, p. 79-93, doi: 10.1016/j.precamres.2013.10.005.

Dickson, J.A.D., 1965, A Modified Staining Technique for Carbonates in Thin Section: Nature, v. 205, no. 4971, p. 587-587, doi: 10.1038/205587a0.

Dix, G.R., Thomson, M.L., Longstaffe, F.J., and McNutt, R.H., 1995, Systematic decrease of high $\delta 13 \mathrm{C}$ values with burial in late Archaean $(2.8 \mathrm{Ga})$ diagenetic dolomite: evidence for methanogenesis from the Crixás Greenstone Belt, Brazil: Precambrian Research, v. 70, no. 3, p. 253-268.

Hartlaub, R.., Heaman, L.., Ashton, K.., and Chacko, T., 2004, The Archean Murmac Bay Group: evidence for a giant Archean rift in the Rae Province, Canada: Archaean Tectonics, Volume 2, v. 131, no. 3-4, p. 345-372, doi: 10.1016/j.precamres.2004.01.001.

Hayes, J.M., and Waldbauer, J.R., 2006, The carbon cycle and associated redox processes through time: Philosophical Transactions of the Royal Society of London B: Biological Sciences, v. 361, no. 1470, p. 931-950, doi: 10.1098/rstb.2006.1840.

Hitzman, M.W., 1999, Routine staining of drill core to determine carbonate mineralogy and distinguish carbonate alteration textures: Mineralium Deposita, v. 34, no. 8, p. 794-798, doi: 10.1007/s001260050240.

Hoffman, P.F., 1988, United Plates of America, The Birth of a Craton: Early Proterozoic Assembly and Growth of Laurentia: Annual Review of Earth and Planetary Sciences, v. 16, no. 1, p. 543-603, doi: 10.1146/annurev.ea.16.050188.002551.

Holland, H.D., 2006, The oxygenation of the atmosphere and oceans: Philosophical Transactions of the Royal Society B-Biological Sciences, v. 361, no. 1470, p. 903-915.

Karhu, J.A., 1993, Paleoproterozoic evolution of the carbon isotope ratios of sedimentary carbonates in the Fennoscandian Shield: Geologian tutkimuskeskus.

Karhu, J.A., and Holland, H.D., 1996, Carbon isotopes and the rise of atmospheric oxygen: Geology, v. 24, no. 10, p. 867-870, doi: 10.1130/00917613(1996)024<0867:CIATRO>2.3.CO;2. 
399

400

401

402

403

404

405

406

407

408

409

410

411

412

413

414

415

416

417

418

419

420

421

422

423

424

425

426

427

428

429

430

431

432

433

434

435

436

Kump, L.R., Junium, C., Arthur, M.A., Brasier, A., Fallick, A., Melezhik, V., Lepland, A., Črne, A.E., and Luo, G., 2011, Isotopic evidence for massive oxidation of organic matter following the Great Oxidation Event: Science, v. 334, no. 6063, p. 1694 -1696, doi: 10.1126/science. 1213999.

Maheshwari, A., Sial, A.N., Gaucher, C., Bossi, J., Bekker, A., Ferreira, V.P., and Romano, A.W., 2010, Global nature of the Paleoproterozoic Lomagundi carbon isotope excursion: A review of occurrences in Brazil, India, and Uruguay: Precambrian Isotope Stratigraphy Symposium in the 33rd IGC, v. 182, no. 4, p. 274-299, doi: 10.1016/j.precamres.2010.06.017.

Martin, A.P., Condon, D.J., Prave, A.R., and Lepland, A., 2013, A review of temporal constraints for the Palaeoproterozoic large, positive carbonate carbon isotope excursion (the Lomagundi-Jatuli Event): Earth-Science Reviews, v. 127, no. 0, p. 242-261, doi: 10.1016/j.earscirev.2013.10.006.

Master, S., Bekker, A., and Karhu, J.A., 2013, Paleoproterozoic high $\delta 13$ Ccarb marbles from the Ruwenzori Mountains, Uganda: Implications for the age of the Buganda Group: Chemical Geology, v. 362, p. 157-164, doi: 10.1016/j.chemgeo.2013.10.005.

Melezhik, V., Fallick, A., and Clark, T., 1997, Two billion year old isotopically heavy carbon: evidence from the Labrador Trough, Canada: Canadian Journal of Earth Sciences, v. 34, no. 3, p. 271-285.

Melezhik, V.A., Fallick, A.E., Medvedev, P.V., and Makarikhin, V.V., 1999, Extreme 13Ccarb enrichment in ca. 2.0 Ga magnesite-stromatolite-dolomite-'red beds' association in a global context: a case for the world-wide signal enhanced by a local environment: Earth-Science Reviews, v. 48, no. 1-2, p. 71-120, doi: 10.1016/S0012-8252(99)00044-6.

Melezhik, V.A., Fallick, A.E., Smirnov, Y.P., and Yakovlev, Y.N., 2003, Fractionation of carbon and oxygen isotopes in 13C-rich Palaeoproterozoic dolostones in the transition from medium-grade to high-grade greenschist facies: a case study from the Kola Superdeep Drillhole: Journal of the Geological Society, v. 160, no. 1, p. 71-82, doi: 10.1144/0016-764902-008.

Norrish, K., and Hutton, J.., 1969, An accurate X-ray spectrographic method for the analysis of a wide range of geological samples: Geochimica et Cosmochimica Acta, v. 33, no. 4, p. 431-453, doi: 10.1016/0016-7037(69)90126-4.

Partin, C.A., Bekker, A., Planavsky, N.J., Scott, C.T., Gill, B.C., Li, C., Podkovyrov, V., Maslov, A., Konhauser, K.O., Lalonde, S.V., Love, G.D., Poulton, S.W., and Lyons, T.W., 2013, Large-scale fluctuations in Precambrian atmospheric and oceanic oxygen levels from the record of $U$ in shales: Earth and Planetary Science Letters, v. 369-370, no. 0, p. 284-293, doi: 10.1016/j.eps1.2013.03.031. 
Planavsky, N.J., Bekker, A., Hofmann, A., Owens, J.D., and Lyons, T.W., 2012, Sulfur record of rising and falling marine oxygen and sulfate levels during the Lomagundi event: Proceedings of the National Academy of Sciences, v. 209, no. 45, p. 18300-18305, doi: 10.1073/pnas.1120387109.

Rosenbaum, J., and Sheppard, S.M.., 1986, An isotopic study of siderites, dolomites and ankerites at high temperatures: Geochimica et Cosmochimica Acta, v. 50, no. 6, p. 1147-1150, doi: 10.1016/0016-7037(86)90396-0.

Sahoo, S.K., Planavsky, N.J., Kendall, B., Wang, X., Shi, X., Scott, C., Anbar, A.D., Lyons, T.W., and Jiang, G., 2012, Ocean oxygenation in the wake of the Marinoan glaciation: Nature, v. 489, no. 7417, p. 546-549, doi: 10.1038/nature11445.

Schidlowski, M., Eichmann, R., and Junge, C.E., 1975, Precambrian sedimentary carbonates: carbon and oxygen isotope geochemistry and implications for the terrestrial oxygen budget: Precambrian Research, v. 2, no. 1, p. 1-69, doi: 10.1016/0301-9268(75)90018-2.

Schröder, S., Bekker, A., Beukes, N.J., Strauss, H., and Van Niekerk, H.S., 2008, Rise in seawater sulphate concentration associated with the Paleoproterozoic positive carbon isotope excursion: evidence from sulphate evaporites in the $\square 2.2-2.1 \mathrm{Gyr}$ shallow-marine Lucknow Formation, South Africa: Terra Nova, v. 20, no. 2, p. 108-117, doi: 10.1111/j.1365-3121.2008.00795.x.

Scott, C., Lyons, T.W., Bekker, A., Shen, Y., Poulton, S.W., Chu, X., and Anbar, A.D., 2008, Tracing the stepwise oxygenation of the Proterozoic ocean: Nature, v. 452, no. 7186 , p. 456-459, doi: 10.1038/nature06811.

Scott, C., Wing, B.A., Bekker, A., Planavsky, N.J., Medvedev, P., Bates, S.M., Yun, M., and Lyons, T.W., 2014, Pyrite multiple-sulfur isotope evidence for rapid expansion and contraction of the early Paleoproterozoic seawater sulfate reservoir: Earth and Planetary Science Letters, v. 389, no. 0, p. 95-104, doi: 10.1016/j.epsl.2013.12.010.

Swart, P.K., Burns, S.J., and Leder, J.J., 1991, Fractionation of the stable isotopes of oxygen and carbon in carbon dioxide during the reaction of calcite with phosphoric acid as a function of temperature and technique: Chemical Geology: Isotope Geoscience section, v. 86, no. 2, p. 89-96, doi: 10.1016/01689622(91)90055-2.

Tang, H., Chen, Y., Wu, G., and Lai, Y., 2011, Paleoproterozoic positive $\delta 13$ Ccarb excursion in the northeastern Sino-Korean craton: Evidence of the Lomagundi Event: Gondwana Research, v. 19, no. 2, p. 471-481, doi: 10.1016/j.gr.2010.07.002.

Valley, J.W., 1986, Stable isotope geochemistry of metamorphic rocks: Reviews in Mineralogy and Geochemistry, v. 16, no. 1, p. 445-489. 
476 Yudovich, Y.E., Makarikhin, V.V., Medvedev, P.V., and Sukhanov, N.V., 1991, Carbon 477 isotope anomalies in carbonates of the Karelian Complex: Geochem. Int, v. 28, p. $478 \quad 56-62$.

479

480 
481 Tables.

482

483 Table 1. Measured carbon and oxygen isotope values for both whole rock and micro-

484 drilled metacarbonate samples. Precision for $\delta^{13} \mathrm{C}$ and $\delta^{18} \mathrm{O}$ values is $0.05 \%$ and $0.11 \%$, 485 respectively.

486

487 Table 2. Mineral assemblages of select metacarbonate samples based on stained thin 488 section petrography.

489

490 Table 3. Chemical composition of whole-rock metacarbonate samples $\left(\mathrm{MgO}, \mathrm{CaO}, \mathrm{CO}_{2}\right.$,

491 and $\left.\delta^{13} \mathrm{C}\right)$ and calculated values of the amount of decarbonation $(F), \Delta^{13} \mathrm{C}$ (CO2-carb), and

492 therefore shifted carbon isotopic values.

493

494 Table 4. Compilation of select highly positive $\delta^{13} \mathrm{C}$ values representing the Lomagundi

495 Event from Maheshwari et al. (2010), and the maximum and minimum values for our

496 MBG samples. 


\section{Figure Captions.}

498

499 Figure 1. Upper: Craton map of the western Churchill province (Rae and Hearne cratons)

500 and Slave craton, highlighting Paleoproterozoic successions of the southern Rae craton

501 (Ashton and Hartlaub 2008). Lower: Geological map of the Murmac Bay Group (Ashton

502 et al. 2007) and surrounding area including sample locations in this study.

504 Figure 2. A generalized tectonostratigraphic column of the Murmac Bay Group (see 505 Geological Setting for details), with carbon isotope values from this study plotted in 506 stratigraphic context.

508 Figure 3. A. Photomicrograph (in cross-polar) showing the typical appearance of

509 twinned dolomite within the MBG metacarbonate rocks. B. Photomicrograph showing 510 the typical appearance of the tremolite overgrowth (bladed rhombs) of the 511 metamorphosed calcite. Calcite also shows twinning, consistent with metamorphic 512 recrystallization.

514 Figure 4. A. Cross-plot of $\delta^{13} \mathrm{C}$ vs. $\delta^{18} \mathrm{O}$ for both whole-rock and micro-drilled samples.

515 B. Cross-plot of Si content vs. the F value for each whole-rock metacarbonate sample, 516 showing the linear relationship between increased loss of carbon (lower $\mathrm{F}$ values) and 517 higher Si content. 
1.75-1.60 Ga

Sedimentary Rocks

1.84-1.74 Ga

Sedimentary Rocks

Circa 1.8 Ga Orogens

$1.92-1.82 \mathrm{Ga}$

Sedimentary Rocks

Circa 1.9 Ga Orogens

2.33-1.91 Ga

Sedimentary Rocks

Other Paleoproterozoic

Successions

Undifferentiated

Archean Crust
Phanerozoic Cover


Lake

Athabasca
1.75-1.6 Ga Athabasca Group 1.82 Ga Martin Group Anatectic Leucogranite

Murmac Bay Group

$\square$ Mixed Supracrustal Rocks

Psammopelitic-Pelitic Rocks

Mafic Volcanic Rocks

Gabbro-Ultramafic Rocks

Quartzite

2.3 Ga Granitoids

Orthogneiss

2.6 Ga Granitoids

3.0 Ga Granitoids 


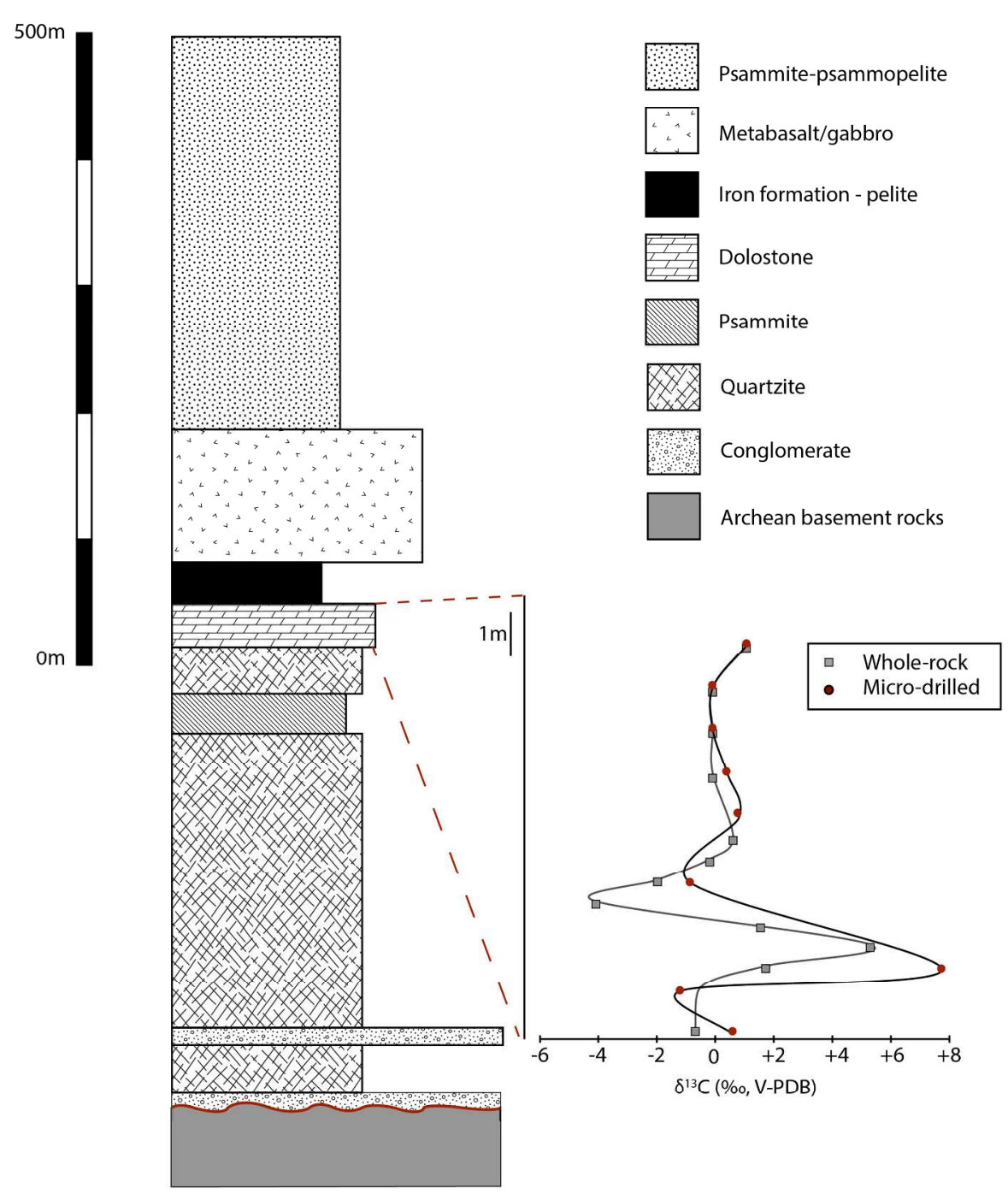

A generalized tectonostratigraphic column of the Murmac Bay Group (see Geological Setting for details), with carbon isotope values from this study plotted in stratigraphic context. $215 \times 233 \mathrm{~mm}(300 \times 300 \mathrm{DPI})$ 


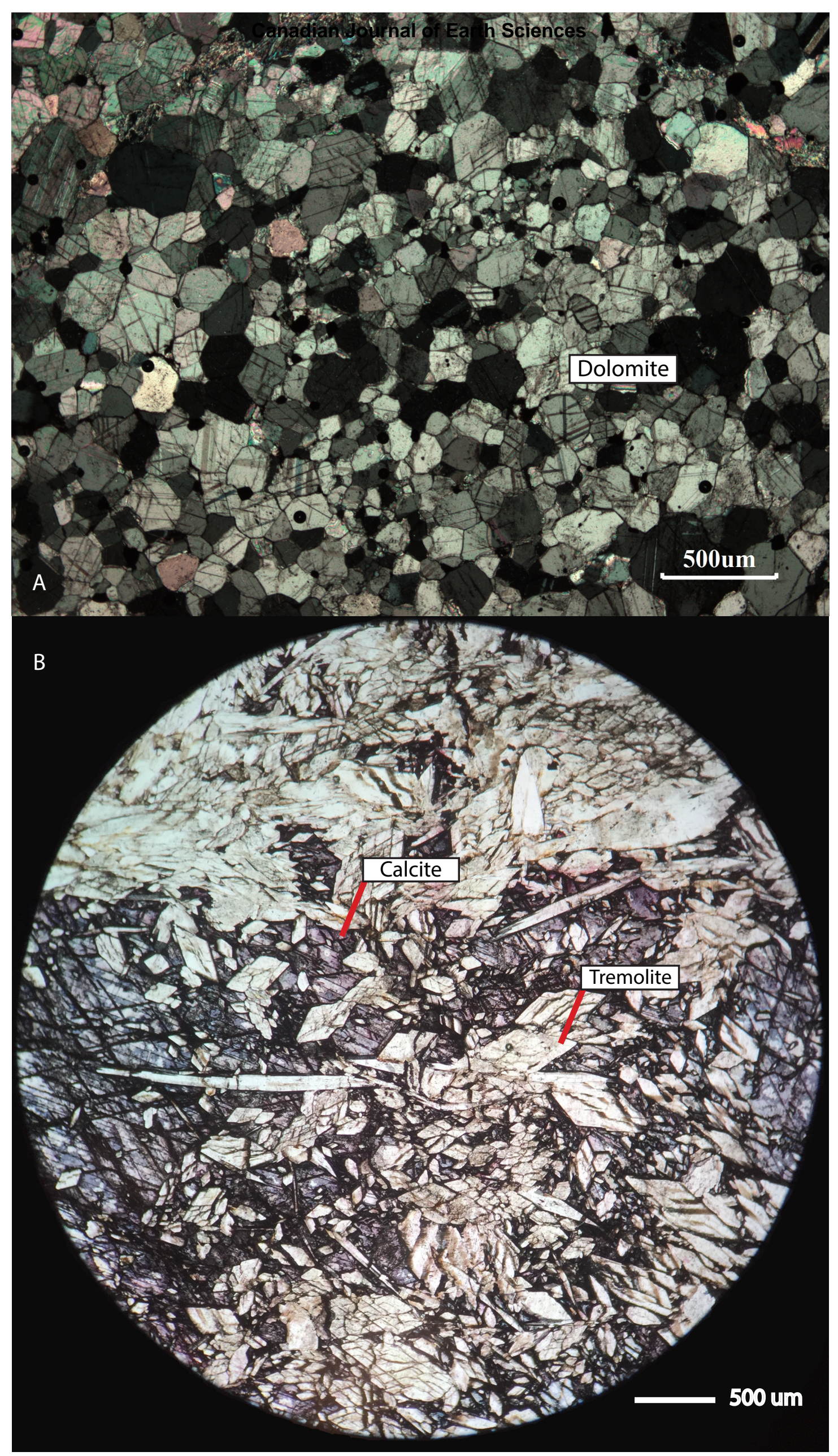




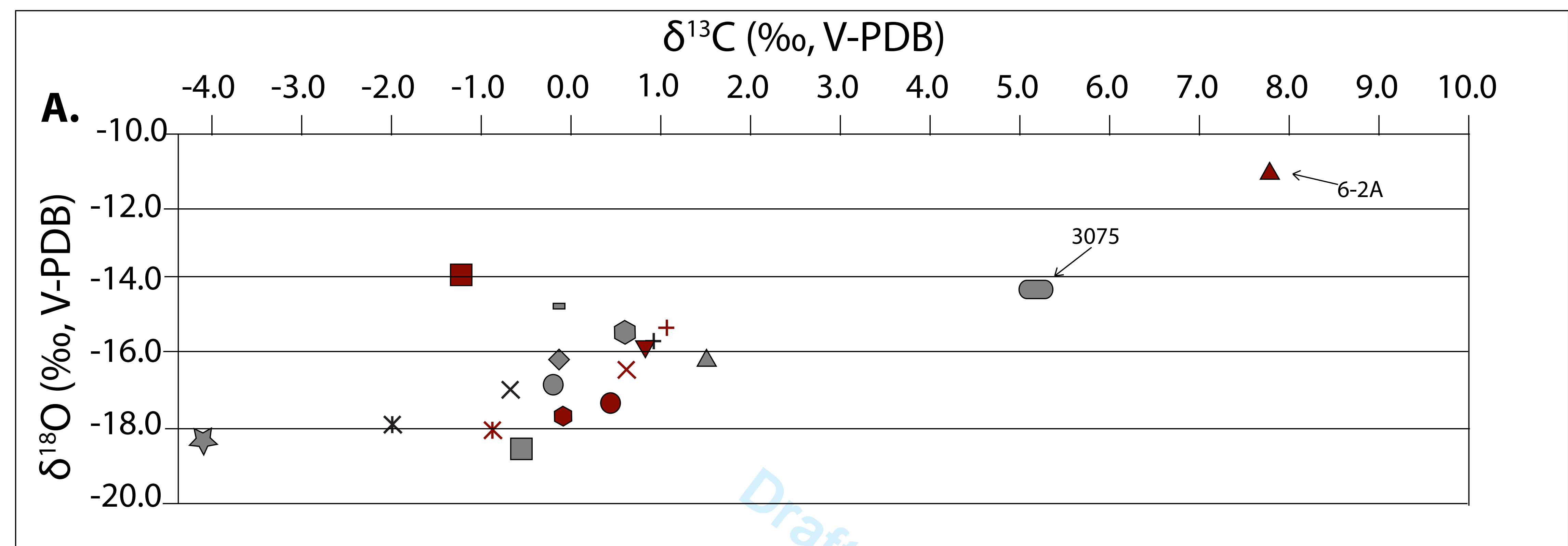

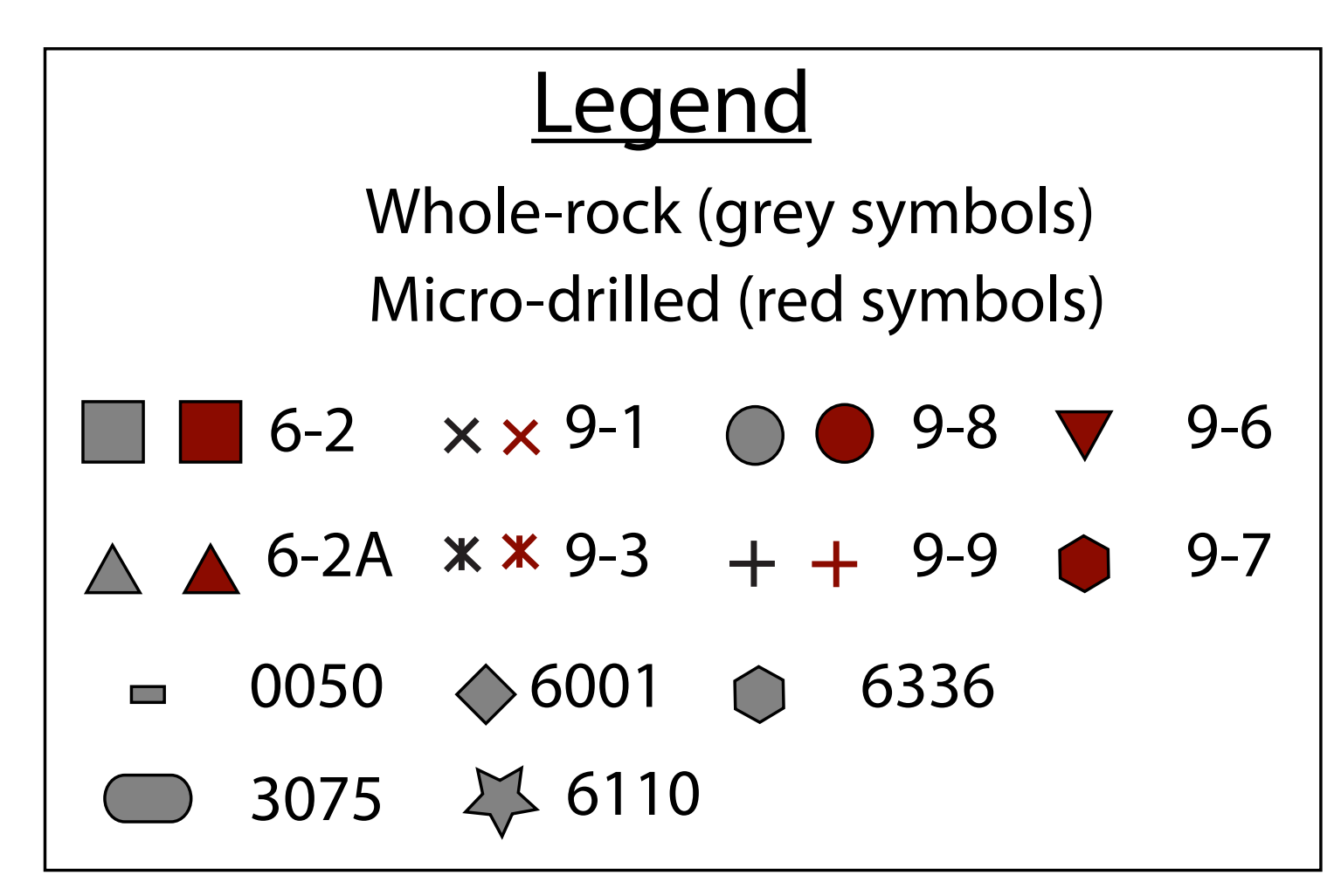

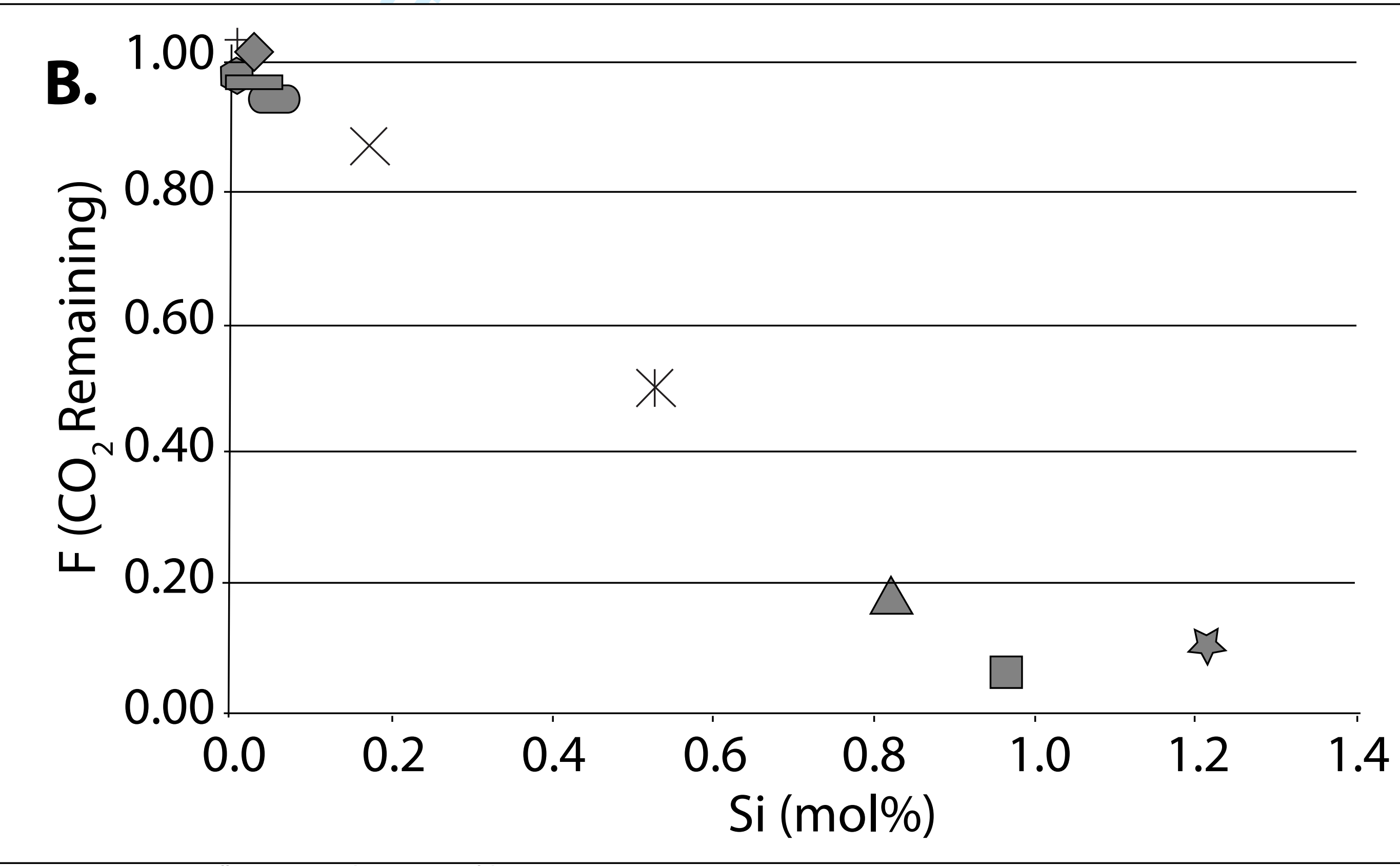


Table 1.

\begin{tabular}{|c|c|c|c|}
\hline Sample \# & $\boldsymbol{\delta}^{\mathbf{1 3}} \mathbf{C}$ (\%o, V-PDB) & $\boldsymbol{\delta}^{\mathbf{1 8}} \mathbf{O}$ (\%o, V-PDB) & Sample type \\
\hline \hline $6-2$ & -0.5 & -18.4 & whole rock \\
\hline $6-2 \mathrm{~A}$ & 1.7 & -16.1 & whole rock \\
\hline $9-1$ & -0.7 & -16.8 & whole rock \\
\hline $9-3$ & -2.0 & -17.8 & whole rock \\
\hline $9-8$ & -0.1 & -16.7 & whole rock \\
\hline $9-9$ & 1.1 & -15.5 & whole rock \\
\hline 0050 & -0.2 & -14.5 & whole rock \\
\hline 3075 & 5.3 & -14.0 & whole rock \\
\hline 6001 & -0.1 & -16.0 & whole rock \\
\hline 6110 & -4.1 & -18.3 & whole rock \\
\hline 6336 & 0.6 & -15.3 & whole rock \\
\hline & & & Microdrilled mineral \\
\hline $6-2$ & -1.2 & -13.7 & Dolomite \\
\hline $6-2 \mathrm{~A}$ & 7.8 & -10.9 & Dolomite \\
\hline $9-1$ & 0.6 & -16.3 & Calcite \\
\hline $9-3$ & -0.9 & -18.0 & Calcite \\
\hline $9-6$ & 0.8 & -15.6 & Calcite \\
\hline $9-7$ & -0.1 & -17.6 & Calcite \\
\hline $9-8$ & 0.4 & -17.2 & Calcite \\
\hline $9-9$ & 1.1 & -15.1 & Calcite \\
\hline
\end{tabular}




\begin{tabular}{|c|c|c|c|c|c|c|c|}
\hline Sample \# & Calcite & Ferroan Calcite & Dolomite & Ferroan Dolomite & Tremolite & Magnetite & Quartz \\
\hline $6-2$ A & $\mathbf{X}$ & & & & $\mathbf{X}$ & & \\
\hline $6-2$ & & & $\mathbf{X}$ & & $\mathbf{X}$ & & $\mathbf{X}$ \\
\hline $9-1$ & & & $\mathbf{X}$ & & $\mathbf{X}$ & & \\
\hline $9-3$ & & $\mathbf{X}$ & & $\mathbf{X}$ & $\mathbf{X}$ & $\mathbf{X}$ & \\
\hline $9-4$ & $\mathbf{X}$ & $\mathbf{X}$ & $\mathbf{X}$ & & $\mathbf{X}$ & & \\
\hline $9-6$ & & & $\mathbf{X}$ & & & $\mathbf{X}$ & \\
\hline $9-7$ & $\mathbf{X}$ & $\mathbf{X}$ & & & & & \\
\hline $9-8$ & & & $\mathbf{X}$ & & $\mathbf{X}$ & $\mathbf{X}$ & \\
\hline $9-9$ & & & $\mathbf{X}$ & & & $\mathbf{X}$ & $\mathbf{X}$ \\
\hline
\end{tabular}


Table 3.

$\mathrm{wt} \%$

$\mathrm{mol} \%$

$\begin{array}{llllllllll}\text { Sample \# } & \mathrm{MgO} & \mathrm{CaO} & \mathrm{CO} 2 & \delta^{13} \mathrm{Cf} & \mathrm{MgO} & \mathrm{CaO} & \mathrm{CO}_{2} & \mathrm{CO}_{2} \text { necessary } & \mathrm{CO}_{2} \text { Lost }\end{array}$

\begin{tabular}{|c|c|c|c|c|c|c|c|c|c|c|c|c|c|c|}
\hline & & & & & & & & & & & & & & \\
\hline $6-2$ & 14.59 & 14.08 & 1.64 & -1.2 & 362 & 251 & 37 & 613 & 576 & 0.06 & 1.003 & 3 & 1.04 & Dolomite \\
\hline 6-2A & 22.62 & 16.33 & 6.69 & 1.7 & 561 & 291 & 152 & 852 & 700 & 0.18 & 1.004 & 4 & 1.39 & Dolomite \\
\hline 6110 & 2.85 & 1.65 & 0.46 & -4.1 & 71 & 29 & 10 & 100 & 90 & 0.10 & 1.005 & 5 & 1.73 & Dolomite \\
\hline $9-3$ & 15.53 & 25.16 & 18.4 & -0.9 & 385 & 449 & 418 & 834 & 416 & 0.50 & 1.01 & 12 & 0.62 & Dolomite \\
\hline $9-1$ & 16.66 & 28.02 & 34.90 & 0.6 & 413 & 500 & 793 & 500 & -293 & 0.63 & 1.00 & -1 & 0.59 & Calcite \\
\hline $9-8$ & 15.73 & 28.63 & 34.60 & 0.4 & 390 & 511 & 786 & 511 & -276 & 0.65 & 1.00 & -1 & 0.55 & Calcite \\
\hline $9-9$ & 17.43 & 29.44 & 43.60 & 1.1 & 432 & 525 & 991 & 525 & -466 & 0.53 & 1.00 & -2 & 0.59 & Calcite \\
\hline 0050 & 20.11 & 29.13 & 43.60 & -0.2 & 499 & 519 & 991 & 519 & -471 & 0.52 & 1.00 & 0 & 0.69 & Calcite \\
\hline 3075 & 20.61 & 30.25 & 43.50 & 5.3 & 511 & 539 & 988 & 539 & -449 & 0.55 & 0.99 & -9 & 0.68 & Calcite \\
\hline 6336 & 0.27 & 29.99 & 44.60 & 0.6 & 7 & 535 & 1013 & 535 & -479 & 0.53 & 1.00 & -1 & 0.66 & Calcite \\
\hline 6001 & 19.9 & 51.40 & 41.40 & -0.1 & 494 & 917 & 941 & 917 & -24 & 0.97 & 1.00 & 4 & 0.01 & Calcite \\
\hline
\end{tabular}


Table 4.

\begin{tabular}{|c|c|c|c|}
\hline $\begin{array}{l}\text { Location } \\
\text { North America }\end{array}$ & Lithology & $\begin{array}{l}\delta^{13} \mathrm{C} \\
\text { Min. }\end{array}$ & $\begin{array}{l}\delta^{13} \mathrm{C} \\
\text { Max. }\end{array}$ \\
\hline $\begin{array}{c}\text { Murmac Bay Group } \\
\text { Micro-drilled } \\
\text { Whole-rock }\end{array}$ & Dolostone & $\begin{array}{l}-1.2 \\
-4.1\end{array}$ & $\begin{array}{l}7.8 \\
5.3\end{array}$ \\
\hline Africa & & & \\
\hline Mcheka Formation & Dolostone & 2.6 & 13.6 \\
\hline Norah Formation & Dolostone & 5.6 & 16.6 \\
\hline Francevillian Series & Dolostone & 2.6 & 6.3 \\
\hline Gumbu Group & Limestone & 4.7 & 7 \\
\hline Duitschland Formation & Dolostone & -2.0 & 10.1 \\
\hline Ruwenzori Mountains & Dolostone & 1.4 & 11.3 \\
\hline Sengoma-Silverton & $\begin{array}{l}\text { Dolostone and } \\
\text { Limestone }\end{array}$ & 8.3 & 11.2 \\
\hline $\begin{array}{l}\text { Lucknow Formation } \\
\text { Australia }\end{array}$ & Dolostone & 8.7 & 10.4 \\
\hline $\begin{array}{l}\text { Bubble Well Member, } \\
\text { Juderina Formation } \\
\text { India }\end{array}$ & Dolostone & 5.7 & 8.8 \\
\hline $\begin{array}{l}\text { Jhamarkotra Formation } \\
\text { South America }\end{array}$ & Dolostone & 5.4 & 11.2 \\
\hline Cercadinho Formation & Dolostone & 3.3 & 5.4 \\
\hline Fecho do Funil Formation & Dolostone & 5.6 & 7.4 \\
\hline $\begin{array}{l}\text { Rio Itapicuru Greenstone } \\
\text { Belt }\end{array}$ & Dolostone & 5.5 & 9 \\
\hline $\begin{array}{l}\text { Itabuna-Salvador-Curaca } \\
\text { orogen }\end{array}$ & Dolostone & 2.2 & 6.9 \\
\hline Guarinos greenstone belts & Dolostone & -0.7 & 14.5 \\
\hline Rio de la Plata craton & Dolostone & -5.6 & 11.6 \\
\hline
\end{tabular}

